\title{
GLOBALIZACJA I JEJ ODZWIERCIEDLENIE W PROCESACH NOMINACYJNYCH JĘZYKA ROSYJSKIEGO
}

\author{
ANNA ROMANIK \\ Uniwersytet w Biatymstoku \\ a.romanik@uwb.edu.pl
}

ORCID: 0000-0002-2733-6503

\section{STRESZCZENIE}

Celem niniejszej publikacji jest zaakcentowanie wpływu procesów globalizacyjnych na współczesny język rosyjski, głównie na poziomie nominacji językowej. Autorka skupia się na dwóch sposobach nazewniczych takich, jak: zapożyczanie leksyki obcojęzycznej oraz słowotwórstwo kompozycyjne, których popularność ewidentnie wynika między innymi z nabierającej na sile tendencji umiędzynarodowienia kontaktów różnych narodów na świecie. Zarówno pożyczki, jak i derywowane na bazie modelu obcego złożenia są rezultatem dominacji języka z angielskiego w skali całego świata. Angielski w niniejszej publikacji jest rozpatrywany jako narzędzie globalizacji indukujące dość poważne dysproporcje w produktywności poszczególnych technik nazewniczych w systemie nominacyjnym języka rosyjskiego.

SŁOWA KLUCZOWE: dyskurs medialny, globalizacja, język rosyjski, kompozycja, nominacja językowa, zapożyczanie.

\section{GLOBALIZATION AND ITS REFLECTION IN THE NOMINATION PROCESSES OF THE RUSSIAN LANGUAGE}

ABSTRACT

The aim of the article is to highlight the impact of globalization process on the contemporary Russian language, mainly on linguistic nomination system. The author focuses on two naming methods (means), such as, borrowing foreign-language lexis and phenomenon of compounding, whose popularity is clearly a result of, among others, the growing tendency to internationalize contacts between various nations all over the world. Both loans and compound words derived from a foreign word-formative models appear as a result of English dominance in the whole world. In this paper English is considered as a tool of globalization inducing quite serious disproportions in the productivity of particular naming techniques in Russian language.

KEYWORDS: borrowing, compounding, globalization, linguistic nomination, media discourse, Russian language.

\section{UWAGI WSTĘPNE}

Zgodnie z definicją słownikową termin globalizacja oznacza „proces zachodzący we współczesnym świecie, przede wszystkim dzięki postępowi telekomunikacji i informatyki oraz przekształceniom gospodarczym, polegającym na powstawaniu coraz silniejszych związków między odległymi krajami, głównie związków ekonomicznych i kulturowych" (Słownik wyrazów obcych i trudnych, 
2001: 274). Przytoczona definicja dość skrótowo traktuje dane pojęcie, niemniej została odnaleziona w słowniku należącym do nielicznych pozycji leksykograficznych, które w ogóle rejestrują i wyjaśniają ten termin. Jak się okazuje w języku potocznym jest on intuicyjnie używany (często nawet nadużywany), natomiast w obiegu naukowym ze względu na wielopłaszczyznowość znaczenia paradoksalnie okazuje się trudny do zdefiniowania.

W centrum procesów globalizacyjnych umiejscawia się przede wszystkim ekonomię i politykę, jako „lokomotywę współczesnych transformacji” ludzkości (Berezovskaya, Kiriyanova 2009: 144). Jednak znawcy zjawiska wskazują na inne, równie istotne tendencje rozwoju cywilizacyjnego sprzyjające globalizacji. Mowa tu między innymi o pozbawionej granic komunikacji medialnej, intensyfikacji turystyki w obrębie całego globu, rosnącej standaryzacji w sferze techniki, osłabieniu kontroli państwowej nad działalnością transportowa, telekomunikacyjna, farmaceutyczna, o otwartości rynku handlowego, współpracy międzynarodowej różnych organizacji (w tym naukowych), zwiększeniu oferty programów edukacyjnych i możliwości kształcenia poza granicami swojego kraju, internacjonalnym charakterze mody itd. (Ignatenko 2009: 25; Shchennikova 2015: 120). Lilia Kiriyanova podkreśla, że „globalizacja jako rozszerzenie, intensyfikacja i pogłębienie wzajemnego światowego uzależnienia oraz integracji przejawia się we wszystkich aspektach współczesnego życia" (Kiriyanova 2007: 137). Jednym z takich aspektów jest język, jako narzędzie komunikacji międzyludzkiej, żywo reagujące na wszelkie zmiany zachodzące na świecie. Związek między językiem a wszechobecną i nadal postępującą globalizacją stał się przedmiotem zainteresowania wielu lingwistów, co wcale nie oznacza, że temat został wyczerpany. Wręcz przeciwnie, istnieje potrzeba kontynuacji opisu tego aktualnego zjawiska, które B. Stelingowska (2017: 27-28) określa jako postępowe, nieuniknione i narastające.

Niniejsza publikacja stanowi próbę uzupełnienia dotychczasowego dorobku slawistów poszukujących powiązań postępu cywilizacyjnego $\mathrm{z}$ faktorem lingwistycznym. Jak anonsuje tytuł artykułu, założeniem podjętych rozważań jest wskazanie wpływu globalizacji na język rosyjski, a dokładniej - na procesy nominacyjne. Główny cel stanowi zidentyfikowanie i opis dominacji tendencji onomazjologicznych we współczesnej ruszczyźnie, uwarunkowanych transformacjami o charakterze społeczno-kulturowymi zachodzącymi na całym świecie. Badanie ograniczono do języka dyskursu medialnego, który, jak powszechnie wiadomo, w tempie błyskawicznym rejestruje wszelkie nowości językowe odzwierciedlające otaczającą rzeczywistość. (Raciburskaya, Samylicheva, Shumilova 2016: 134). Materiał faktograficzny (innowacje leksykalne, precyzyjniej - rzeczowniki) zaczerpnięto z rosyjskojęzycznych czasopism lifestylowych typu glamour (Elle, Glamour, Harper's Bazaar, Vogue) opublikowanych w ostatnim trzyleciu. Wybór tego rodzaju mediów był podyktowany ich międzynarodowym charakterem oraz profilem tematycznym, 
skoncentrowanym na promocji współczesnej ideologii konsumpcyjnej będącej rezultatem komercjalizacji wielu dziedzin życia. Zatem wydaje się, że tego typu prasa sama $\mathrm{w}$ sobie jest obecnie narzędziem globalizacji i tym samym odzwierciedla ją w sposób werbalny (zmaterializowany, ponieważ w formie pisanej).

\section{GlobAlizACJA A NOMinACJA}

Dychotomiczne zestawienie obu pozornie odległych od siebie pojęć (globalizacji i nominacji) w odniesieniu do otaczającej nas rzeczywistości jest kontekstualnie słuszne, ponieważ wyraża silną zależność między pojęciami. Demonstruje ono bowiem powiązanie rozwoju cywilizacyjnego i działalności człowieka z jej wytworami, jakim, na przykład, jest język. Bezspornym jest fakt, że nominacja językowa w dużej mierze jest kreowana przez czynniki ekstralingwistyczne. Wpływ globalizacji w procesach nominacyjnych jest również istotny, a nawet można stwierdzić, że coraz silniejszy. Zanim jednak wskażę istotę zależności między obydwoma pojęciami, warto wyjaśnić, co w teorii lingwistycznej oznacza „nominacja językowa” i jak jest realizowana w ruszczyźnie.

Nominacja językowa jest zjawiskiem polisemicznym. Encyklopedia językoznawcza (Больиой энциклопедический словарь. Языкознание 1998: 336) podaje trzy definicje tego terminu. W skrócie, nominacja jest rozumiana jako proces nadawania nazwy fragmentom rzeczywistości, jest także utożsamiana $z$ jednostką językową będącą wytworem procesu nazewniczego, a także oznacza zbiór problemów lingwistycznych korelujących z procesem nazywania, związanych ze słowotwórstwem, polisemia, frazeologią itd. W zaproponowanych rozważaniach termin nominacja językowa jest używany w pierwszym z wymienionych znaczeń, jako proces nadawania nazwy różnym artefaktom.

Przedmiotem zainteresowania nominacji językowej są między innymi techniki (środki formalne), mechanizmy i sposoby nadawania nazw. Jak wiadomo, każdy odrębny język dysponuje arsenałem swoistych, zindywidualizowanych technicznych możliwości gramatycznych. Niemniej jednak większość języków posiada „uniwersalne”, wspólne sposoby nominacji językowej, których produktywność (dominacja lub marginalizacja) w zależności od języka przedstawia się w sposób zróżnicowany (Romanik 2012: 50).

W systemie nazewniczym języka rosyjskiego, zgodnie z klasyfikacją zaproponowaną przez D. N. Shmeleva (1982: 37), można wyróżnić pięć zasadniczych sposobów nominacji:

- słowotwórstwo morfologiczne - afiksalne,

- derywację semantyczną,

- kompozycję,

- zapożyczanie elementów obcego pochodzenia,

- słowotwórstwo analityczne (tworzenie nazw w postaci zestawień 
wyrazowych).

System nazwotwórczy ruszczyzny wykrystalizował się na przestrzeni wielu stuleci i dziś, w XXI wieku, zabezpiecza możliwość tworzenia nowych jednostek językowych. Należy podkreślić, że obecnie pod wpływem wszystkich powyżej wskazanych przejawów globalizacji niektóre techniki nominacyjne stają się coraz bardziej produktywne, inne natomiast odchodzą na peryferie. Badany zakres słownictwa jest jaskrawym przykładem dominacji dwóch zasadniczych sposobów nazywania: zapożyczania oraz derywowania nazw złożonych. Podjęte badania ograniczą się do opisu tych sposobów nominacji. Wynika to $\mathrm{z}$ faktu, że popularność ich jest wypadkową różnych przyczyn, wśród których procesy globalizacyjne mają swój szczególny udział. Natomiast produktywność pozostałych technik nazewniczych nie jest uzależniona od procesów „umiędzynarodowienia” różnych sfer życia na świecie, stąd też decyzja o ich pominięciu.

\section{ZAPOŻYCZANIE WYRAZÓW OBCYCH JAKO DOMINANTA NOMINACJI JĘZYKOWEJ}

Współcześnie proces zapożyczania, jak twierdzi E.V. Marinova, wyróżnia się, po pierwsze, olbrzymim zasięgiem, totalnościa, zróżnicowanym wpływem na wszystkie poziomy i sfery języka, a po drugie, wpływem na mentalność Rosjan. Ponadto dodaje ona, że cechą transferu leksykalnego jest jego internacjonalny charakter, ponieważ aktywne zjawisko przenikania zapożyczeń obserwowany jest $\mathrm{w}$ wielu językach świata, nawet $\mathrm{w}$ takich, które reprezentują stosunkowo zamknięte systemy, genetycznie różniące się od języków indoeuropejskich, na przykład, w japońskim czy chińskim (Marinova 201: 36). Natomiast językiemdawcą $w$ procesie importu językowego jest przede wszystkim angielszczyzna, która zyskała status ,języka międzynarodowej komunikacji” i jest nazywana współczesnym lingua franca czy, jak wolą inni badacze, językiem globalnym (Slesareva 2017: 79).

Angielski jest nierozłącznym elementem, a w zasadzie można powiedzieć - bardzo ważnym narzędziem procesów globalizacyjnych, które ułatwia unifikację, integrację i nawiązywanie wszelkiego rodzaju kontaktów między narodami mówiącymi w różnych językach. Stał się on językiem biznesu i dyplomacji, międzynarodowych publikacji (w tym naukowych), konferencji i forów, kinematografii, sztuki, sportu, reklamy itd. Zresztą bez wspólnego wektora językowego umożliwiającego lepsze porozumiewanie się w obrębie całego globu wszelkie procesy cywilizacyjne zapewne nie osiagnęłyby takiej skali, jak dotychczas.

Obecność pożyczek angielskich w badanych czasopismach jest mocno zauważalna. Szczególnie wysoką frekwencję wyrazów obcych odnotowano w takich grupach tematycznych, jak:

- telefonia, komputeryzacja, Internet (w tym słownictwo portali społecznościowych), пр. аккаунт, блогинг, диджитал-детокс, имейл, 
кибербуллинг, лайк, месседж, мессенджер, ноутбук, офлайн, пост, роуминг, селфи/сәлфи, сисадмин, скайп, скриншот/скрин-иот, смартфон, снэпчат, тачскрин, твит, твиттер, тролиинг, фолловер, фотошоп, хештег/хэитег,

- moda (odzież, fryzjerstwo, biznes modowy, shoping), np. aymфum, байер, барбершоп, бондинг, брашинг, броу-бар, джемпер, дизайн, ковошинг, концетп-стор, корнер, хук, массмаркет/масс-маркет, мастхэв, оверсайз, пушап, свитиот, стайлинг, стилист, стритстайл, тотал-лук, фәиионист(а), фешн/фешен, иоу-рум,

- kosmetologia, medycyna estetyczna, np. антиэйdж, глайd, глиттер, контуринг, хайнер, хипосакция, хипофилинг, хифтинг, мейкап, пирсинг, фейслифтинг, хайлайтер,

- sztuka, np. apmхаусlapm-хаус, перформер, перформанс, стрит-арт,

- show business, kino, film, np. байопик, блокбастер, бэкстейдж, реалитищоу, саундтрек, селебрити/селебритис, спин-офф, ток-иоу,

- bankowość, finanse, biznes, np. банкинг, биткойн, блокчейн, коин, краудфандинг, кәшбек/кешбәк, ноу-хау,

- rynek pracy (w tym określenia zawodów), np. бебиситтер, ивентменеджер, консалтинг, лай

- turystyka, hotelarstwo, podróże, np. коттедж, лобби, лоукостер, ресепшен, рум-сервис,

- kulinaria (trendy dietetyczne, filozofia jedzenia, nazwy potraw), np. джусинг, кофе-брейк, ханч-бокс, смузи, стейк-хаус, стритфуд, фастинг, фастфуд, фудиеринг, читмил,

- nowe postawy i zachowania społeczne, np. бархоппинг, бодипозитив, инсайдер, инфлюенсер, каминг-аут, каучсёрфинг, лайфстайл, АГБТ, метросексуал, миллениал, олдскул, сталкер, трендсеттер, фрилансер, фристайл, хипстер,

- sport, nр. вейкбординг, воркаут, сайкхинг, снорклинг,

- rynek wydawniczy, np. колумнист, таблоид.

Wyraźnym przejawem procesu globalizacji jest również przybierająca na sile tendencja do zapożyczania słownictwa obcego pochodzenia $\mathrm{w}$ postaci wtrętów językowych w oryginalnej łacińskiej grafice języka, będącego źródłem importu leksykalnego. Oczywiście przyczyn tak zwanej „latynizacji” ruszczyzny jest wiele, ale dążenie do integracji (także pisma) z innymi narodami, kosmopolityzacji teksów prezentowanych w czasopismach jest ewidentny. Dla przykładu można przytoczyć kilka cytatów zaczerpniętych z badanych czasopism: «Перед заветным путешествием в Страну восходящего солнци Бреанна собирается навестить меня в Москве: «почувствовать крещенские морозы, закутавиись в меховые платки, как настоящал russian girl» («Vogue» июнь 2018: 55); «Уединённый курорт располагает әлегантными номерами, сьютами и двухэтажными виллами, в которых есть всё дя беззаботного отдыха: кровати king size, кофемашины Nespresso, wi-fi и «умная» техника» («Elle» 
апрель 2017: 318); «Делаю то же самое - и буквально не верю своим глазам: даже мой простой чёрный total look из блузки и джинсов приобрёл неожиданный гламурный лоск» («Vogue» февраль 2018: 99); «Этой привычкой активно пользуются в культурной среде, выстраивая произведения согласно логике компьютерного видения. А некоторые даже подчиняются ей полностью - как продюсер Тимур Бакмамбетов, запустивиий в 2013 году изельй продакшн, посвящённый жанру lifescreen» («Elle» сентябрь 2018: 156); «Аня развивает не самое известное в России направление aerostretching (растяжка в воздухе с помощью специиальных ремней). Как это выглядит (обалденно) и к чему приводит - хорошо видно на её аккаунте» («Glamour» июнь 2018: 60); - «У каждого дизайнера свой power dressing - одежда, в которой женщина чувствует себя просто привлекательной, но ещё и способной свернуть горы» («Elle» май 2017: 43).

Warto także dodać, że zapożyczanie, jako sposób nominacji językowej, nie ogranicza się jedynie do transferu leksykalnego, czyli jednostek wyrazowych, a dotyczy także innych poziomów języka, na przykład, morfologii i składni. Język rosyjski bowiem chętnie sięga także do arsenału formantów słowotwórczych pochodzenia anielskiego (-инг, мега-, суnер-), czy nawet całych konstrukcji składniowych.

\section{SŁOWOTWÓRSTWO KOMPOZYCYJNE W DOBIE GLOBALIZACJI}

Derywacja wyrazów złożonych w języku rosyjskim od dawna zajmuje silną pozycję w systemie nazewniczym języka rosyjskiego. Niemniej początek XXI wieku to okres, w którym wielu językoznawców obserwuje nasilenie tendencji tworzenia struktur złożonych. Uwzględnienie kompozycji jako sposobu nominacji, którego produktywność jest w sporej mierze podyktowana powszechną globalizacją ma swoje uzasadnienie. Chodzi o sytuację, kiedy dominującym wzorem tworzenia kompozycji stają się anglojęzyczne standardy słowotwórcze. Mowa tu o bezinterfiksalnych złożeniach rzeczownikowych, które, jak się okazuje, odnotowuje się w wielu systemach językowych na świecie. Polska badaczka, A. Witalsz (2018: 45-46), określa tego typu composita jako „formacje hybrydalne tworzone seriami na zasadzie analogii do angielskich modeli strukturalnych". Autorka zwraca uwage również na dodatkowy aspekt dotyczący neozłożeń, mianowicie, używając stwierdzenia w pewien sposób zabarwionego pejoratywnie, mówi o nich jak o "efekcie ubocznym" intensywnego zapożyczania angielszczyzny.

W rosyjskiej lingwistyce problem „nowych” złożeń jest szeroko dyskutowany ze względu na ogromną skalę zjawiska oraz ze względu na trudności i konsekwencje, jakie indukuje obecność tych struktur w języku (problemy natury ortograficznej, wariantywność i niestabilność pisowni, dylematy kodyfikacyjne itd.).

W analizowanych czasopismach można odnaleźć ogromną ilość wyrazów złożonych, jednak należy pamiętać, że wiele z nich posiada status zapożyczeń 
właściwych, a nie derywatów sensu srticto, np. реалити-иоу, сторителлинг, mотал-лук, щорт-лист. Przytoczone jednostki stanowią szablon modelowy do tworzenia struktur binarnych na gruncie języka rosyjskiego. W konsekwencji mnożą się wyrazy złożone ze znajdującą się w prepozycji podstawą wyrażoną najczęściej zapożyczonym rzeczownikiem, nieodmiennym $\mathrm{w}$ danym kontekście i określającym atrybut nazywanego desygnatu. W rosyjskiej literaturze przedmiotu funkcjonują różne nazwy takich konstrukcji, np. „аналитконструкции", „сложения атрибутивной модели”, „агглютинативные структуры" itd. (Marinova 2016: 41; Raciburskaya, Samylicheva, Shumilova 2016: 153). Za przykład omawianej struktury słowotwórczej mogą posłużyć następujące jednostki: анти-эйдж-методика, арт-линия, арт-мир, арт-тусовка, бъюти-компания, бъюти-намерение, бьюти-помощница, бъюти-страшилки, фэин-история, оиtdoor-тренировки, такеир-средство. Wśród przytoczonych egzemplifikacji znalazły się także ciekawe formacje hybrydalne, które w obrębie jednej struktury są zlepkiem dwóch różnych grafii (łacinki i cyrylicy).

\section{UWAGI KOŃCOWE}

W podsumowaniu można stwierdzić, że wpływ globalizacji na język rosyjski, w tym na procesy nominacyjne, jest znaczący. Jak pisze A. Strawińska „w skali globalnej coraz większa liczba ludzi ma zbliżony styl życia, współbieżne aspiracje zawodowe i konsumpcyjne, podobnie się odżywia, ubiera czy spędza wolny czas" (Strawińska 2018: 149). Takie tendencje są zauważalne w podejmowanej tematyce analizowanych czasopism lifestylowych, i w języku, który jest werbalnym odzwierciedleniem zmian unifikacyjnych zachodzących na całym świecie. Niniejsze rozważania pokazują że z lingwistycznej perspektywy niezwykle istotnym "narzędziem” globalizacji jest dziś niepodważalnie język angielski. Stał się on pomostem łączącym nieraz odległe bardzo narody, stwarza ogromne możliwości komunikacji i wszelkiego rodzaju kontaktu ludzkości na Ziemi. Z przeprowadzonej analizy wynika, że na popularność angielskiego $\mathrm{w}$ sposób ewidentny reaguje także system nazewniczy współczesnego języka rosyjskiego, co wyraźnie widać na przykładzie takich sposobów nominacji, jak: zapożyczanie leksyki obcojęzycznej (przede wszystkim anglo-amerykańskiej proweniencji) czy też słowotwórstwo kompozycyjne oparte na modelu charakterystycznym dla angielszczyzny. Wpływy obce obserwowane $\mathrm{w}$ mentalności, postawach i działaniu Rosjan wywołane powszechną globalizacją mają swój poważny udział w zmianach na poziomie leksyki oraz na poziomie stosunkowo konserwatywnej gramatyki. 


\section{LITERATURA}

BEREZOVSKAYA, KIRIYANOVA: БЕРЕЗОВСКАЯ, О.М., КИРЬЯНОВА, Л.Г. (2009), «Тенденции этноязыковых процессов в условиях глобализации современного общества», Известия Томского политехнического университета, т. 315, № 6, 144148.

IGNATENKO: ИГНАТЕНКО, И.И. (2009), «Языковые и коммуникативные процессы в эпоху глобализации», Наука и школа, №3, 24-27.

KIRIYANOVA: КИРЬЯНОВА, А.Г. (2007), Общество в контексте глобально-локальных отношений, Томск, Дельтаплан.

KULESHOVA: КУЯЕШОВА, Н.А. (2011), «Язык моды в эпоху глобализации (об англоамериканских заимствованиях в русской, испанской и французской версиях журнала Vogue)», Вестник Российского университета дружбы народов. Серия: Аингвистика, 73-84.

MARINOVA: MAРИНОВA, Е.В. (2016), «Освоение новых заимствований и сопутствующие процессы в русском языке начала XXI века», Новые тенденциии в русском языке начала ХХІ века, Рацибурская, А.В. (ред.), Москва, Флинта, Наука, 36-133.

RACIBURSKAYA, SAMYLICHEVA, SHUMILOVA: РАЦИБУРСКАЯ, Л.В., САМЫЛИЧЕВА, Н.А., ШУМИЛОВА, А.В. (2016), «Новые тенденции в современном медийном словотворчестве», Новые тенденции в русском языке начала ХХІ века, Рацибурская, Л.В. (ред.), Москва, Флинта, Наука, 134-221.

ROMANIK, A. (2012), Sposoby nominacji przedmiotów odzieży we wspótczesnym języku rosyjskim, Białystok, Wydawnictwo Uniwersytetu w Białymstoku.

SLESAREVA: CлECAPEBA, A.A. (2017), «Глобализация ангдийского языка», Вестник ВолГУ, Серия 9, вып. 15, 78-81.

SHCHENNIKOVA: ЩЕННИКОВА, Н.В. (2015), «Языковой фактор глобализации», Век глобализациии, №2, 119-129.

SHMELEV: ШМЕАЕВ, Д.Н., ред., (1982), Способы номинации в современном русском языке, Москва, Наука.

Słownik wyrazów obcych i trudnych, (2001), Markowski, A., Pawelec, R. (red.), Warszawa.

STELINGOWSKA, B. (2017), «Globalizacja językowo-kulturowa», Literatura i globalizacja, Kur, E.M., Stelingowska, B. (red.), Siedlce, Wydawnictwo Uniwersytetu Przyrodniczo-Humanistycznego w Siedlcach, 27-38.

STRAWIŃSKA, A.B. (2018), «Wpływ globalizacji i nowych technologii na zachowania językowe współczesnych Polaków», Pogranicze. Studia Społeczne, t. XXXII, 145-166.

WALCZAK, B. (2016), «Globalizacja językowa - przejawy i prognozy», Globalizacja a przemiany języków słowiańskich, Kurek, H., Święcicka, M., Peplińska, M. (red.), Bydgoszcz, Wydawnictwo Uniwersytetu Kazimierza Wielkiego.

WITALISZ, A. (2018), «Contact-Induced Right-Headed Interfixless N+N Compounds in Polish. A Corpus Based Studies», Studies in Polish Linguistics, 13(1), 45-46.

Большой энцикиопедический словарь. Языкознание, (1998), Ярцева, В.Н. (ред.) Москва. 